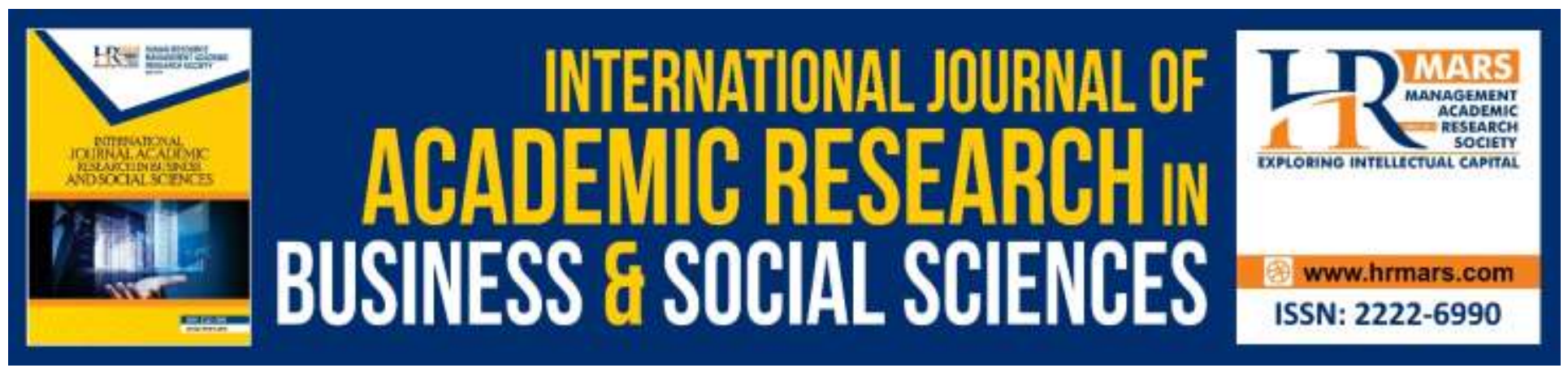

\title{
Transition to Low Carbon Economy through Carbon Dioxide Emission Reduction in Power Generation Sector in Malaysia
}

Audrey Liwan, Mohd Khairul Hisyam Hassan, Jerome Kueh Swee Hui, Rosita Hamdan, Josephine Yau Tan Hwang, Candice Kok

To Link this Article: http://dx.doi.org/10.6007/IJARBSS/v9-i7/6113

DOI: $10.6007 /$ IJARBSS/v9-i7/6113

Received: 22 May 2019, Revised: 27 June 2019, Accepted: 07 July 2019

Published Online: 30 July 2019

In-Text Citation: (Liwan et al., 2019)

To Cite this Article: Liwan, A., Hassan, M. K. H., Hui, J. K. S., Hamdan, R., Hwang, J. Y. T., \& Kok, C. (2019).

Transition to Low Carbon Economy through Carbon Dioxide Emission Reduction in Power Generation Sector in Malaysia. International Journal of Academic Research in Business and Social Sciences, 9(7), 246-258.

\section{Copyright: (C) 2019 The Author(s)}

Published by Human Resource Management Academic Research Society (www.hrmars.com)

This article is published under the Creative Commons Attribution (CC BY 4.0) license. Anyone may reproduce, distribute, translate and create derivative works of this article (for both commercial and non-commercial purposes), subject to full attribution to the original publication and authors. The full terms of this license may be seen

at: http://creativecommons.org/licences/by/4.0/legalcode

Vol. 9, No. 7, 2019, Pg. 246 - 258

http://hrmars.com/index.php/pages/detail/IJARBSS

JOURNAL HOMEPAGE

Full Terms \& Conditions of access and use can be found at http://hrmars.com/index.php/pages/detail/publication-ethics 


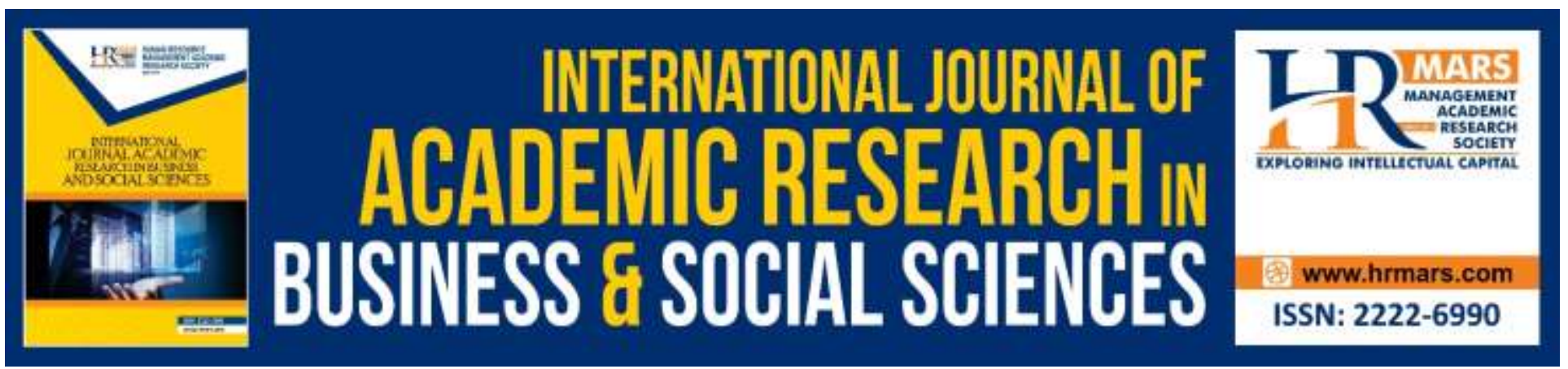

\title{
Transition to Low Carbon Economy through Carbon Dioxide Emission Reduction in Power Generation Sector in Malaysia
}

\author{
Audrey Liwan ${ }^{1,2}$, Mohd Khairul Hisyam Hassan ${ }^{1}$, Jerome Kueh \\ Swee Hui ${ }^{1}$, Rosita Hamdan ${ }^{1}$, Josephine Yau Tan Hwang ${ }^{1}$, Candice \\ Kok $^{1}$ \\ ${ }^{1}$ Affiliation: Faculty Economics and Business, Universiti Malaysia Sarawak, 94300 Kota Samarahan, \\ Sarawak, Malaysia \\ Email: laudrey@unimas.my
}

\begin{abstract}
The economy growth is always the attention focal point to all country. However, the economy growth impacts the protecting environment and vice-versa. The contradiction between the environment and the development of economy are getting more serious. The low carbon economy should be one of the future choice for sustainable development. This study attempts to examine the reduction of carbon dioxide $\left(\mathrm{CO}_{2}\right)$ emission through different scenarios of economic growth and renewable energy mixed. There are three scenarios developed, namely Business-As-Usual (BAU), Ambitious 1 (AMB 1) and Ambitious 2 ( $A M B$ 2). Scenario analysis method and Long-range Energy Alternatives Planning System (LEAP) model were employed in this study. The results show AMB 1 was the most ideal scenario to strike the balance between economic development and environmental sustainability. It is recommended that power generation sector should opt for more renewable energy such as biomass, solar pv and small hydropower. In addition, integration between government agency, suppliers' and consumers' were needed to achieve Malaysia's commitment to reduce carbon emission.
\end{abstract}

Keywords: Low Carbon Economy, Sustainable Development, Environment, Economic Growth, Carbon

\section{Introduction}

Low-carbon economy (LCE) was defined as an economy relied on low carbon power sources which release minimal greenhouse gas (GHG) into the air (Regions for Sustainable Change, 2013), but particularly referred to carbon dioxide (Levy, 2010). The power generation sector was regarded as 
essential service industry that generates, transmit, distribute and sell electric power to the public (Górniak \& Kossowska 2013). The reduction of carbon dioxide emission in power generation sector could be achieved through the utilization of technologies or process during electricity generation such as clean air technology. With the invention, power with substantially lower amounts of carbon dioxide emissions than those who was emitted by conventional fossil fuel power generation could be produced. As time passed, the amount of carbon dioxide released into the environmental would decrease and the problem of global warming could be curbed. As the economy was slowly decarbonizing, the transition of Malaysia from mixed economy to low carbon would be taken place. In Malaysia, there were three major power utilities under power generation sectors in Malaysia which were Tenaga Nasional Berhad (TNB), Sabah Electricity Sdn. Bhd. (SESB) and Sarawak Energy Berhad (SEB). These leading power generation entities can contribute to mitigate the carbon emission through adoption of mixed energy sources.

In Malaysia the environmental policy has been given emphasize since the implementation of Sixth Malaysia Plan (Economic Planning Unit, 1990) and it continued under the Seventh Malaysia Plan, Eight Malaysia Plan, Ninth Malaysia Plan and Tenth Malaysia Plan and current Malaysia Plan. Through these all five years' plan, environmental management was directly integrated into the national planning and project. Under the new economic model (NEM) which was introduced in Tenth Malaysia Plan (Economic Planning Unit 2010), sustainable theme strategies were the main theme. The sustainability principles are focusing on the use of natural resources for a country who has intended to enhance national income. Malaysia also involved in several international agreements in term of environmental issues. During the 21th Conference of Parties (COP21) in 2015, Paris Agreement was negotiated and enforced on 4th November 2016. There were a hundred and ninety-seven countries had signed the Paris Agreement targeted to reduce carbon emissions by 2030.

This agreement was a legally binding universal climate deal and had established a global action plan to urge the world in the mitigation of the effects of climate change by limiting global warming to well below $2^{\circ} \mathrm{C}$, and, if possible, below $1.5^{\circ} \mathrm{C}$. For Malaysia, the approval had been given by the cabinet for the country to ratify the Paris Agreement. According to Malaysia's INDC (2015), the country anticipated to reduce its GHG emissions intensity (per unit of GDP) by forty-five percent by 2030 compared to the emissions intensity in 2005. This reduction comprises of thirty-five percent on an unconditional basis and a further ten percent conditional upon receipt of climate finance, technology transfer and capacity building from developed countries. Malaysia aimed to achieve its emission reduction targets through a mix of mitigation actions, the removal of carbon emissions by forestry and implementation of various national policies including the National Policy on Climate Change and National Green Technology Policy. Furthermore, the National Renewable Energy Policy and Action Plan (NREPAP) had been launched to provide a secure and sustainable national electricity supply for socio-economic development. 
Climate changes such as global warming became worse as the economy grows due to the result of human practices like emission of Greenhouse gases. Fossil fuel consumption resulted in emission of Greenhouse gases, which was responsible for global warming and climate change. Another global environmental issue that was closely related to climate change and global warming was the natural resource depletion. The world was facing challenges in encountering these environmental issues and tackling the carbon dioxide emission through low carbon technologies and reduction in using nonrenewable energy. Furthermore, the country was encountering the problems on how to prolong the lifespan of the non-RE sources and to find other alternatives to replace the non-RE while not compromising economic development. Transition to low carbon economy should be one of the future choice for sustainable development. Therefore, the main concern of this study was to discover the alternatives to mitigate the $\mathrm{CO}_{2}$ emission in power generation sector by using mix renewable energy resources. While design and formulating a new and forward-looking RE as well as EE Policy, policy makers should be able to take into account of the economic growth and does not exacerbate the carbon dioxide emission from the economic sectors. The concept of sustainable energy and energy efficiency should be incorporated while designing policy to ensure the continuous economic development and environmental conservation in Malaysia.

\section{Literature Review}

\section{Theoretical Background}

Environmental Kuznets curve (EKC)

Environmental Kuznets curve originated from predicti of Kuznets in 1955 that the distribution of income became more unequal in early stage of income growth and then the distribution moved towards greater equality as economic growth continues. Kuznets Curve was used to describe the linkage between estimated levels of environmental quality and per capita income. As claimed by Dinda (2014), it was envisioned to display a long term relationship between environmental impact and economic growth and it outlined an essentially dynamic process of change as income of an economy grew over time, emission level rose first, came to a peak and then started decreasing after a threshold level of income had been crossed. For this study, EKC hypothesis was applied for scenarios simulation.

\section{Literature}

Lemaire (2004) had defined that sustainable energy was the provision of energy such that it met the needs of the future effectively without compromising the ability of future generations to meet their own needs. Sustainable energy had excluded any sources that were obtained from fossil fuels or waste products. This energy was replenishable and was able to reduce greenhouse gas emissions and causes no damage to the environment. If fossil fuels were being consumed at a steady rate, they would expire soon and cause detrimental effect to our planet. As claimed by Rinkesh (2017), fossil fuels were not classified as sustainable energy sources because of their limited amount and would releasing harmful gases causing immense pollution and also, they were not available in all places in the planet. 
In moving towards low carbon economy, energy efficiency is one of a meant in using energy more effectively. Energy efficiency measured differences in how much energy was used to provide the same level of comfort, performance or convenience by the same type of product, building or vehicle (NRCAN, 2016). As asserted by Diesendorf (2007) by adopting more efficient technology or production process, the energy efficiency's improvement could be achieved. Although increasing energy efficiency often costs money up-front, this capital outlay would be returned in the form of reduced energy costs within a short time period in most cases.

Previous studies have discovered that carbon emission was strongly related with gross domestic production (GDP) and industrialization development is the primary cause for energy demand and $\mathrm{CO}_{2}$ emissions expansion (Xu \& Han, 2012; Wang, Nie \& Shi, 2011). Nevertheless, various findings found that carbon emission reduction can be achieved through the adoption of clean energy while maintaining the economic growth. Islas, Manzini and Martinez (2002) had investigated the four scenarios about the environmental futures of electricity generation in Mexico.

The results implied that the renewable and transition scenarios were the only scenarios in which it was possible to had both economic growths in long run and declining greenhouse gases (GHG) and acid rain precursor gases (ARPG) emissions. Preceding research studies have been conducted on scenario analysis (Nakata et al., 2003; Swiatowy, 2011; Chen et al., 2013; Selvakkumaran et al., 2014; Gu, Tan, Zeng \& Mu, 2015; Pambudi et al., 2017) and these studies were conducted in different countries. All the finding revealed a positive implication of renewable energy and transition scenario on society, energy and environmental systems. On the other hand, Aslani and Wong (2014) found technology costs and government polices had greatly affected in promoting and commercial development of renewable energy systems. With the current Malaysian policy on utilization of renewable energy it is expected can achieved the balance between economic growth and environmental sustainability.

\section{Methodology}

This study employed scenario analysis and LEAP model to determine the most appropriate scenario to be applied in the transition to low carbon economy. The variables used were $\mathrm{CO}_{2}$, renewable energy namely biomass, solar photovoltaic (pv), small hydropower and electricity demand, GDP as well as population. The scenario assumption was created base on the National Renewable Energy Policy \& Action Plan (NREPAP) Malaysia by KeTTHA (2009). There are three low carbon technologies with greatest potential in carbon emission reduction which were biomass, solar pv and small hydropower. There were five sub-sectors categorized under power generation sectors in each scenario which were the industrial sector, commercial sector, residential sector, transport sector and agriculture sector according to the statistics of The Malaysia Energy Information Hub (MEIH) under Energy Commission Malaysia (2016). The carbon dioxide emission was classified under these five subsectors in each scenario. 
INTERNATIONAL JOURNAL OF ACADEMIC RESEARCH IN BUSINESS AND SOCIAL SCIENCES Vol. 9, No. 7, July, 2019, E-ISSN: 2222-6990 @ 2019 HRMARS

Scenario analysis is aimed to reflect and provide clearer understanding about the business performance under various future states (TCFD, 2017). There were three scenarios designed in this study which are Business-As-Usual (BAU), Ambitious 1 (AMB 1) and Ambitious 2 (AMB 2). Different GDP growth were assigned to each scenario to investigate the effect of GDP growth towards the carbon dioxide emission while remaining the assumptions for each scenario respectively. The assigned GDP growth for BAU is 5\%, for AMB 1 is $6 \%$ and for AMB 2 is $7 \%$.

LEAP was an integrated, scenario-based modelling tool that could be applied to track energy consumption, production and resource extraction in all sectors of an economy (Heaps, 2016). In this study, LEAP model was employed to evaluate the impacts of renewable energy as an alternative of power resources for the energy system in Malaysia. Basically, as stated by Heaps (2016), this model was used as an instrument to inspect the current energy trend and simulate alternatives energy while considering environmental emissions under the user define assumption. This tool had a Technology and Environmental Database (TED) that could capture the relevant outcomes such as financial and environmental costs and technical feature of different technologies. TED could trace the greenhouse gases and its reduction from a different phase of fuel chain from the extraction of resources, production activity, product distribution, and finally the burning activities.

LEAP also consisted of full energy accounting framework that could analyses the energy demand and supply technologies and generate the impacts on the overall system. The model did not limit to optimal behavior and did not assume energy as the only factor affecting technology selection. This model contained various signals such as price, income levels, and limits on the rate of stock turnover. The analytical procedure in LEAP model was described in Figure 3.1. It could be summarized as five steps: sectoral production projection, corresponding energy demand, CO2 emissions, total cost calculation, energy savings, and CO2 abatement potential calculation (Wang et al., 2007). 
INTERNATIONAL JOURNAL OF ACADEMIC RESEARCH IN BUSINESS AND SOCIAL SCIENCES

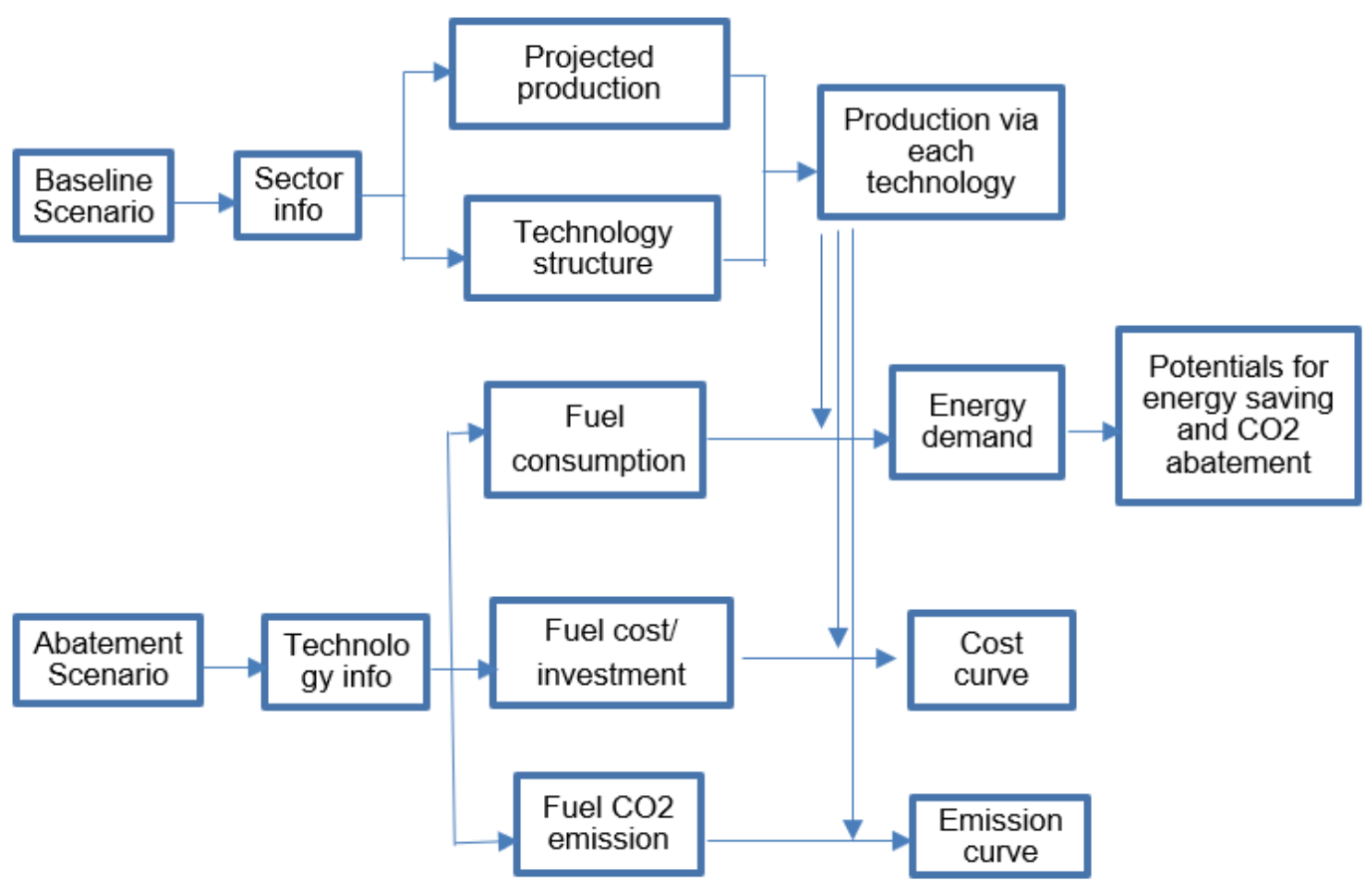

Figure 3.1: Structure and analytical procedure of the LEAP model

\section{Results and Discussion}

The results of the study were based on 3 scenarios namely, Business-As-Usual, Ambitious 1 and Ambitious 2 Scenario. The results were presented in the following section.

\section{Scenario 1: Business as usual (BAU) - GDP growth at 5\%}

Figure 4.1: $\mathrm{CO}_{2}$ Emission by Sectors (BAU)

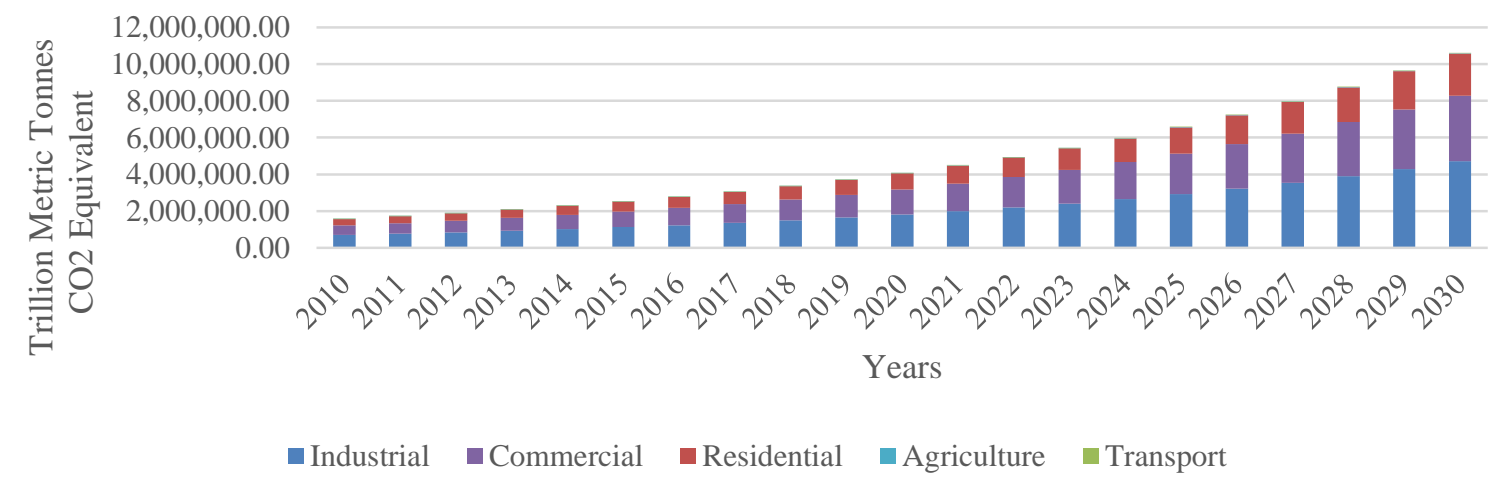

Sources: LEAP software

The First scenario was the Business as Usual (BAU) which employed 5\% GDP growth per annum. Based on figure 4.1, the carbon dioxide emission for all sectors shown constant growth from year 2010 to year 2017. It was simulated that the carbon emission would constantly grow until year 2030 and further without any aggressive measures in reducing carbon emission. The industrial sector was expected to have the highest carbon dioxide emission. The next sector with the second highest $\mathrm{CO}_{2}$ 
INTERNATIONAL JOURNAL OF ACADEMIC RESEARCH IN BUSINESS AND SOCIAL SCIENCES

Vol. 9, No. 7, July, 2019, E-ISSN: 2222-6990 @ 2019 HRMARS

emission was the commercial sector, followed by residential and agriculture sector. The transport sector was contributing the least $\mathrm{CO}_{2}$ emission. For year 2030, all sectors were simulated to have the highest carbon dioxide emission and the total carbon dioxide was 10,615,900.00 Trillion Metric Tonnes $\mathrm{CO}_{2}$ Equivalent in year 2030 .

Scenario 2: Ambitious 1 (AMB 1) - GDP growth at 6\%

Figure 4.2: $\mathrm{CO}_{2}$ Emission by Sectors (AMB 1)

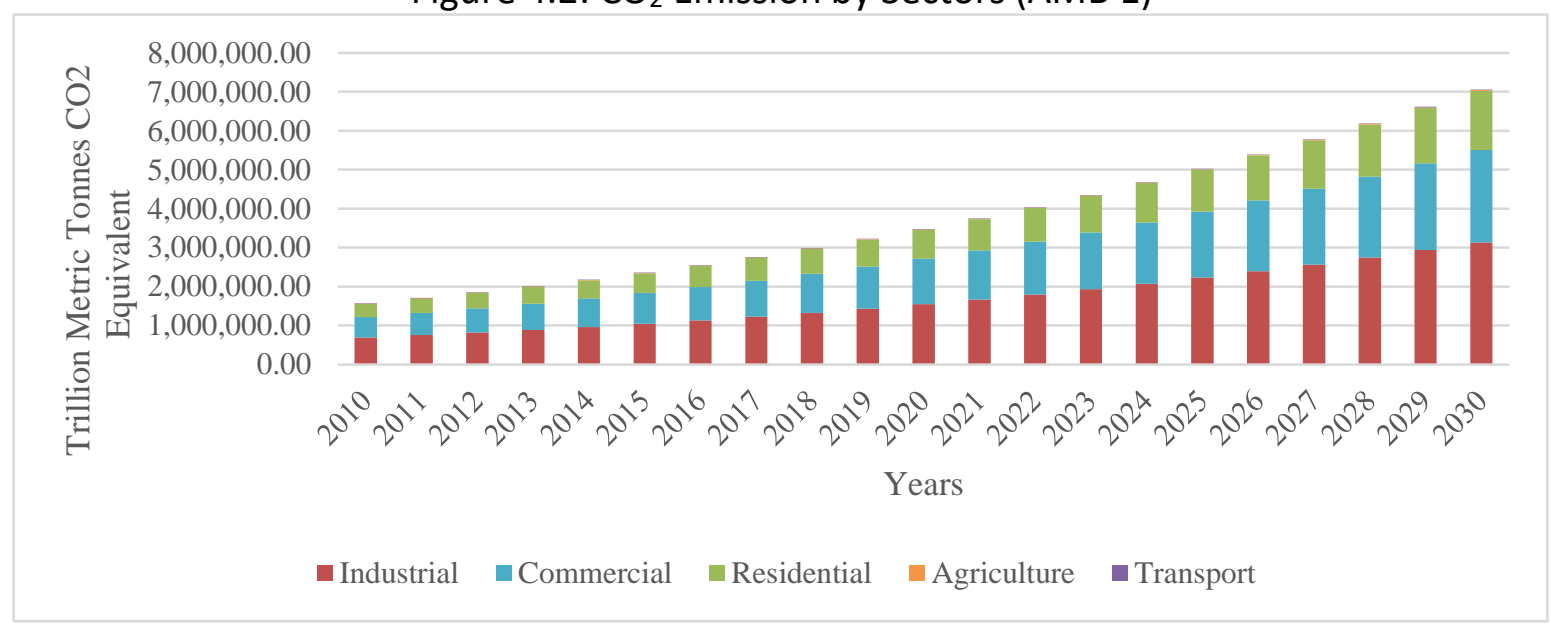

Sources: LEAP software

The second scenario was the Ambitious 1 scenario (AMB 1) that assumed 6\% annual growth. From figure 4.2, the total carbon dioxide emission in all sectors were increasing constantly until year 2030. It clearly showed that the three sectors leading in the carbon emissions were the industrial, commercial and residential sector. The agriculture and transport sectors were contributing insignificantly to the carbon dioxide emission. All sectors were simulated to have the highest carbon dioxide emission in year 2030, which was similar to the BAU scenario.

However, the amount of carbon dioxide in both scenarios were different. The total amount of carbon dioxide emitted in the $A M B 1$ was relatively lower than the BAU scenario due to the utilisation of low carbon technologies in AMB 1. The total carbon dioxide in AMB 1 was 7,057,499.10 Trillion Metric Tonnes $\mathrm{CO}_{2}$ Equivalent in year 2030 compared to 10,615,900.00 in BAU which was 3558400.9 Trillion Metric Tonnes less than the BAU that did not employ any advanced low carbon technology. 
INTERNATIONAL JOURNAL OF ACADEMIC RESEARCH IN BUSINESS AND SOCIAL SCIENCES

Vol. 9, No. 7, July, 2019, E-ISSN: 2222-6990 @ 2019 HRMARS

Scenario 3: Ambitious 2 (AMB 2) - GDP Growth at 7\%

Figure 4.3: $\mathrm{CO}_{2}$ Emission by Sectors (AMB 2)

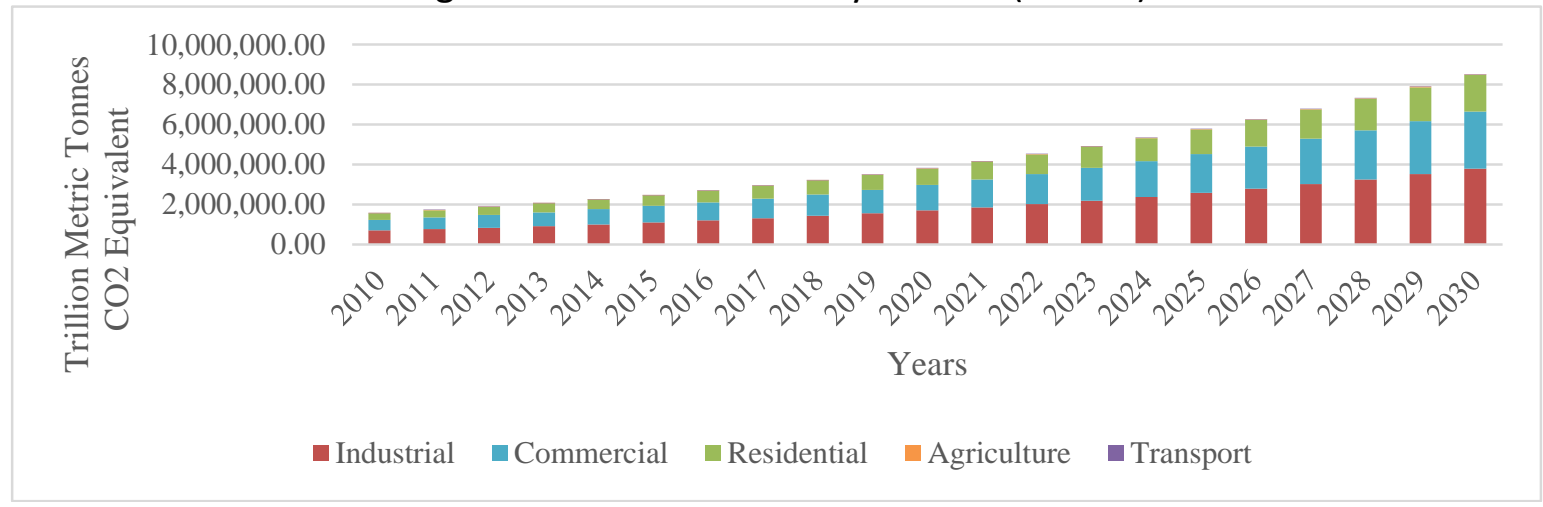

Sources: LEAP software

The third scenario was Ambitious 2 (AMB 2) scenario that assumed 7\% GDP annual growth. From figure 4.3, the total carbon dioxide emission in all sectors were having steady growth to year 2030 as the GDP increases 7\% annually. The simulation shows that the industrial, commercial and residential sector were leading in the carbon emission among all sectors in power generation. The agriculture and transport sectors were contributing insignificantly to the carbon dioxide emission. All sectors were simulated to have the highest carbon dioxide emission in year 2030, which was similar to the BAU scenario and AMB 1.

Figure 4.4 Total $\mathrm{CO}_{2}$ Emission in $\mathrm{BAU}, \mathrm{AMB} 1$ \&AMB 2

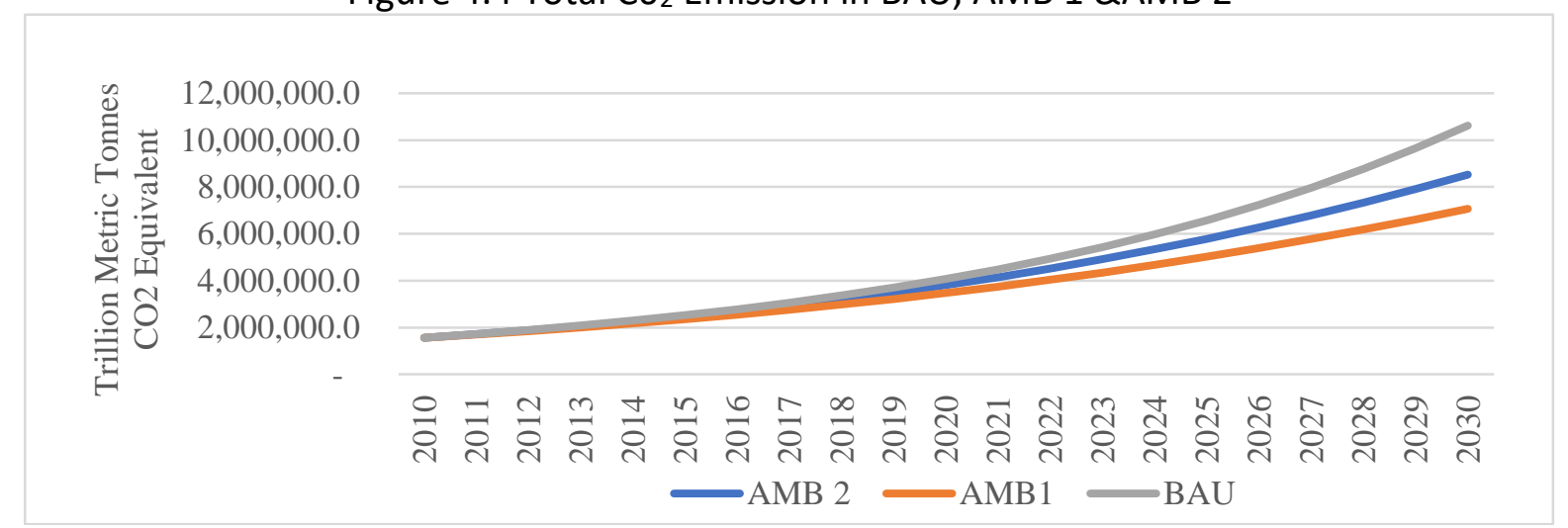

Sources: LEAP software

Nevertheless, in figure 4.4, the amount of carbon dioxide in AMB 2 was different with BAU and AMB 1. The total amount of carbon dioxide emitted in the $A M B 2$ was relatively lower than the $B A U$ scenario but was slightly higher than the AMB 1 scenario. The total carbon dioxide in this scenario was 8515479.00 Trillion Metric Tonnes $\mathrm{CO}_{2}$ Equivalent in year 2030 compared to 10,615,900.00 in BAU and 7,057,499.10 in AMB 1. This was because this scenario had assumed that there was utilisation of low carbon technologies compared to the BAU but at the same time it assumed a higher annual GDP growth that implied more economic activities was taking place and contributed to more 
INTERNATIONAL JOURNAL OF ACADEMIC RESEARCH IN BUSINESS AND SOCIAL SCIENCES

Vol. 9, No. 7, July, 2019, E-ISSN: 2222-6990 @ 2019 HRMARS

carbon dioxide. Hence, the rank of scenarios that emitted the lowest carbon dioxide was AMB 1 to AMB 2 to BAU.

Figure 4.5: Growth rate of $\mathrm{CO}_{2}$ Emission in $\mathrm{AMB} 1$ and $\mathrm{AMB} 2$

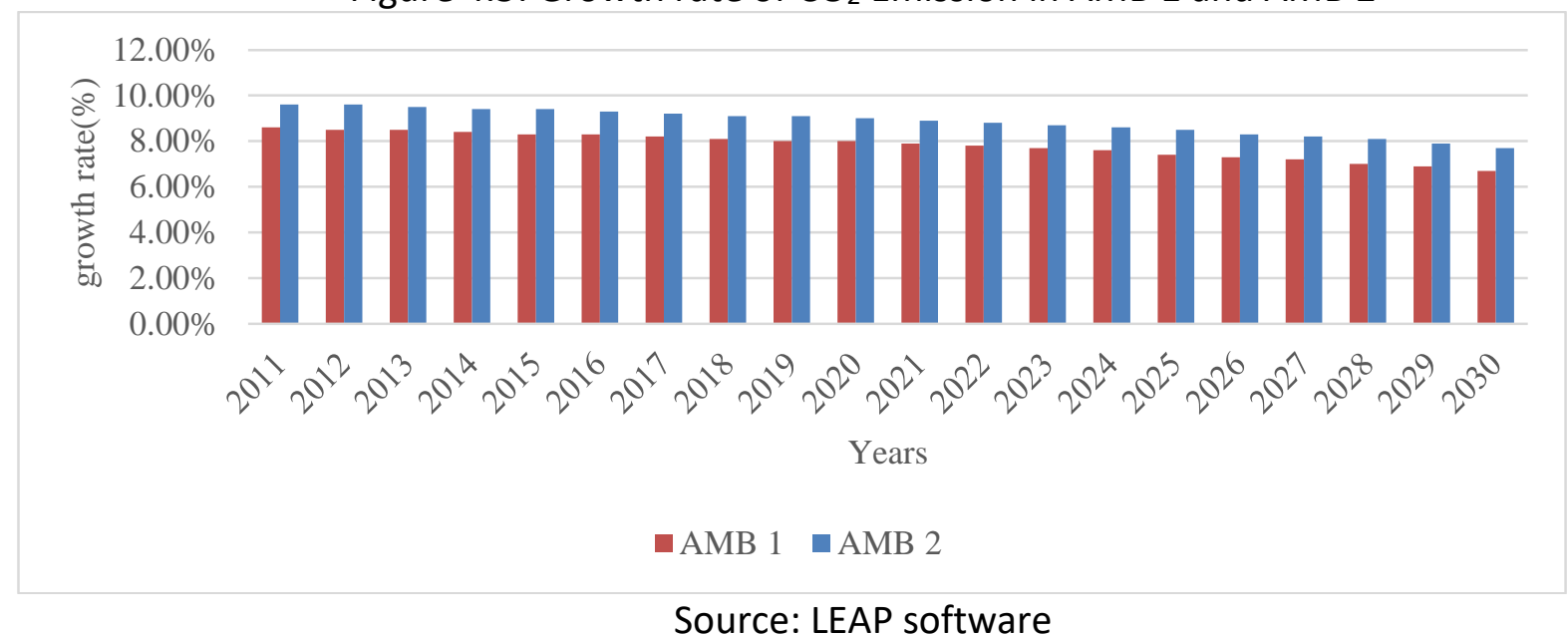

For $A M B 1$ and $A M B$ 2, the percentage of renewable energy in generating power for the five sectors were increased to achieve the target set in Paris Agreement. The increase in RE sources for power generation was one of the efforts as Malaysia had committed to achieve the target of reducing the carbon intensity to $45 \%$ as claimed in the Paris Agreement. From Figure 4.5, by employing the three major RE resources in the Ambitious scenarios which was biomass, solar pv and small hydropower as mentioned in the NREPAP, the growth rate of $\mathrm{CO}_{2}$ emission in $\mathrm{AMB} 1$ and $A M B 2$ were decreasing which meant the emission of carbon dioxide was increasing in a decreasing manner.

However, AMB 1 had shown a greater potential in reducing the carbon dioxide emission because the growth rate of $\mathrm{CO}_{2}$ emission in AMB 1 which employed the GDP growth 6\% was lower than the growth rate in AMB 2. This may due to the higher GDP growth rate in AMB 2 which was $7 \%$ had implied that there were more rapid economic activities. The target RE share in the power generation process such as biomass, solar pv and small hydropower were remained the same in both Ambitious scenarios. Therefore, although both Ambitious scenarios were employing the low carbon technologies, AMB 2 were discovered to have a higher growth rate of $\mathrm{CO}_{2}$ emission as well as the total carbon dioxide emission. and it implied that the engagement level of low carbon technologies could be improved further in AMB 2 scenario to reach a lower outcome of carbon dioxide emission.

From the results, AMB 1 was the more ideal scenario to be applied in the transition of low carbon economy in Malaysia compared to BAU and AMB 2. AMB 1 with 6\% GDP growth was able to strike the balance between economic development and environmental sustainability. From the results, it clearly showed increase in economic growth did not guarantee the reduction in carbon dioxide emission. This was proven in AMB 2 scenario, although the GDP growth was 7\% which was higher than the $6 \%$, the carbon dioxide emission and growth rate of $\mathrm{CO}_{2}$ emission was higher than AMB 1 . 
GDP growth at 7\% was not an ideal scenario to be applied in our transition compared to GDP growth at $6 \%$.

The sustainable economic development was being portrayed better in the AMB 1 compared to AMB 2 and BAU. The economic growth and sustainable environment was able to coexist better and produced a better outcome in carbon dioxide emission in AMB 1 compared to AMB2 and BAU. As incomes rose, demand for a cleaner environment escalated, but so did demand for goods and services that caused pollution: wealthier people wanted more spacious and better heated houses, more energy-consuming domestic appliances, bigger and more powerful cars, and many more. In this scenario, it can be interpreted as the simultaneous increase in incomes and environmental quality was then that the demand for a cleaner environment was met by regulation.

\section{Conclusion}

This study has provided the most appropriate scenario of economic growth and renewable energy mixed for Malaysia economy, in addition, it contributed to the latest understanding on renewable energy implication towards economic and environmental perspectives. From the results obtained, $A M B 1$ had shown a greater potential in reducing the carbon dioxide emission which the growth rate of $\mathrm{CO}_{2}$ emission in $\mathrm{AMB} 1$ was lower than the growth rate in $A M B 2$. It is indicated that $A M B 1$ is the most preferred scenario to be applied in the transition to the low carbon economy in Malaysia compared to AMB 2 and BAU.

The result had implied that our country was able to strike the balance between the economic growth and environmental quality with GDP growth of $6 \%$ in which the carbon dioxide emission was less than the AMB 2 with the similar implementation of Renewable policy and mechanism. By committing efforts to the three major contributors which were industrial, commercial and residential sector, the carbon dioxide emission could be reduced to reach the desired level and to meet sustainable development goal. From the theoretical perspective, this finding had partially complied with the EKC theory that states that the environmental quality was affected by the economic growth. However, the finding also contrasts to the EKC theory, as further increase in GDP growth led to continuous increase carbon emission and there is no turning point.

Hence, this study recommended government should effectively implement the existing national policies such as National Renewable Energy Policy and Action Plan (NREPAP) and National Energy Efficiency Action Plan (NEEAP) to ensure efficient regulatory framework with a good governance system for renewable energy. Furthermore, the economic activities should be guided by environmental policy to minimize the effect of carbon emission and to strike a balance between economic growth and environmental quality to achieve national target on carbon reduction.

\section{Acknowledgment}

The authors would like to thank UNIMAS for the special FRGS Funding with Project ID: F01/SpFRGS/1535/2017 
INTERNATIONAL JOURNAL OF ACADEMIC RESEARCH IN BUSINESS AND SOCIAL SCIENCES

Vol. 9, No. 7, July, 2019, E-ISSN: 2222-6990 @ 2019 HRMARS

\section{References}

Aslani, A., \& Wong, K. F. V. (2014). Analysis of renewable energy development to power generation in the United States. Renewable Energy, 63, 153-161.

Chen, L., Yang, Z., \& Chen, B. (2013). Scenario analysis and path selection of low-carbon transformation in China based on a modified IPAT model. PloS one, 8(10), e77699.

Diesendorf, M. (2007). Greenhouse solutions with sustainable energy (Vol. 20, No. 1). Sydney: University of New South Wales Press.

Energy Commission Malaysia. (2016). Malaysia Energy Statistics Handbook 2016. Kuala Lumpur: Energy Commission.

Gorniak, J., \& Kossowska, M. (2013). Study of Competences-Power Sector-Final Research Report.

Gu, B., Tan, X., Zeng, Y., \& Mu, Z. (2015). CO 2 Emission Reduction Potential in China's Electricity Sector: Scenario Analysis Based on LMDI Decomposition. Energy Procedia, 75, 2436-2447.

Heaps, C. G. (2016). Long-range Energy Alternatives Planning (LEAP) system. [Software version: 2018.1.2] Stockholm Environment Institute. Somerville, MA, USA. https://www.energycommunity.org

INDC Malaysia. (2015). Intended Nationally Determined Contribution (INDC) of the Government of Malaysia. Submitted to the United Nations Framework Convention on Climate Change in 2015.

Islas, J., Manzini, F., \& Martinez, M. (2002). Renewable energies in electricity generation for reduction of greenhouse gases in Mexico 2025. AMBIO: A Journal of the Human Environment, 31(1), 3539.

KeTTHA. (2009). National Renewable Energy Policy \& Action Plan (NREPAP). Malaysia: KEMENTERIAN TENAGA, TEKNOLOGI HIJAU DAN AIR (KeTTHA).

Lemaire, X. (2004). Glossary of terms in sustainable energy regulation. Renewable Energy and Efficiency Partnership, Centre for Management under Regulation, Warwick Business School, University of Warwick.

Levy, C. (2010). A 2020 Low Carbon Economy A Knowledge Economy Programme Report. The Work Foundation.

Nakata, M., Oda, J., Heaps, C., \& Von Hippel, D. (2003). Carbon Dioxide Emissions Reduction Potential in Japan's Power Sector-Estimating Carbon Emissions Avoided by a Fuel-Switch Scenario. Prepared for WWF-Japan.

NRCAN. (2016). Key concepts: energy efficiency. Retrieved December 16, 2017, from http://www.nrcan.gc.ca/energy/efficiency/buildings/eeb/key/3967

Pambudi, N. A., Itaoka, K., Kurosawa, A., \& Yamakawa, N. (2017). Impact of Hydrogen fuel for $\mathrm{CO}_{2}$

Emission Reduction in Power Generation Sector in Japan. Energy Procedia, 105, 3075-3082.

Regions for Sustainable Change (2013): Indicators toolkit. Available on

http://www.rscproject.org/indicators/index.php?page=low-carbon-economy. Accessed April 2013.

Rinkesh. (2017). What was Sustainable Energy and its types. Retrieved December 16, 2017, from https://www.conserve-energy-future.com/sustainableenergy.php

Selvakkumaran, S., Limmeechokchai, B., Masui, T., Hanaoka, T., \& Matsuoka, Y. (2014). An explorative analysis of $\mathrm{CO}_{2}$ emissions in Thai Industry sector under Low Carbon Scenario towards 2050. Energy Procedia, 52, 260-270. 
Swiatowy, B. (2011). Transition to a Low-Emissions Economy in Poland. The World Bank Poverty Reduction and Economic Management Unit, Waszyngton.

TCFD (2017, June). Technical Supplement: The Use of Scenario Analysis in Disclosure of Climaterelated Risks and Opportunities (June 2017). Retrieved from https://www.fsbtcfd.org/publications/final-technical-supplement/

Wang, C., Cai, W., Wang, K., Zhang, Y., \& Chen, J. (2007). Scenario analysis on $\mathrm{CO}_{2}$ emissions reduction potential in China's electricity sector. Energy Policy, 35(12), 6445-6456.

Wang, D., Nie, R., \& Shi, H. Y. (2011). Scenario analysis of China's primary energy demand and $\mathrm{CO}_{2}$ emissions based on IPAT model. Energy Procedia, 5, 365-369.

Xu, M., \& Han, W. (2012). Pathways to a low-carbon economy for Inner Mongolia, China. Procedia Environmental Sciences, 12, 212-217. 